\title{
WEAK MONOTONICITY AND CHEBYSHEV TYPE INEQUALITY
}

\author{
JiA Jin WEN, JosiP PEČARIĆ AND TIAN YONG HAN
}

Abstract. The weak monotonic function is defined in this paper. We will study the relationship between the weak monotonic function and the Schur-function. We show that a Schur-convex function is a weak increasing function under the proper hypotheses. By means of the theory of weak monotonic function with appropriate assumptions, we have established a Chebyshev type inequality as follows:

$$
\frac{\langle\mathbf{a}, \mathbf{b}\rangle}{\left\langle\mathbf{a}^{*}, \mathbf{b}^{*}\right\rangle} \geqslant \frac{\|\mathbf{a}\|_{p}}{\left\|\mathbf{a}^{*}\right\|_{p}} \cdot \frac{\|\mathbf{b}\|_{q}}{\left\|\mathbf{b}^{*}\right\|_{q}} .
$$

As the application of the inequality, a new proof of Marshall's inequality is obtained.

Mathematics subject classification (2010): 26D15.

Keywords and phrases: Weak monotonic function, Schur-function, Chebyshev's inequality, Marshall's inequality.

\section{REFERENCES}

[1] J. E. PeČarić, F. Proschan And Y. L. Tong, Convex functions, partial orderings, and statistical applications, Academic Press Inc, 1992.

[2] I. Franjić, S. Khalid And J. PeČarić, On the refinements of the Jensen-Steffensen's inequality, J. Inequal. Appl. 2011, 2011:12, 11 pp.

[3] J. Cheng AND G. X. LI, The sharpening of Erdös-Florians's inequality, J. Ninbo Univ. 2 (2) (1989), pp. 12-14 (in Chinese).

[4] Z. L. WANG, Inequalities of the Rado-Popoviciu type for functions and their applications, J. Math. Anal. Appl. 100 (1984), pp. 436-446.

[5] J. J. Wen, T. Y. HAN AND S. S. Cheng, Inequalities involving Dresher variance mean, Journal of Inequalities and Applications, 2013, 2013: 366, http://www . journalof inequalitiesandapplications.com/content/2013/1/366.

[6] A. W. Marshall AND I. OlKin, Inequalities: Theory of majorization and its applications, Academic Press, New York, 1979.

[7] P. S. Bullen, D. S. Mitrinović and P. M. Vasić, Means and their inequalities, Reidel, Dordrecht/Boston/Lancaster/Tokyo, 1988.

[8] D. S. Mitrinović, J. E. PeČArić And A. M. Fink, Classic and new inequalities in analysis, Kluwer Academic Publishers, 1993.

[9] P. R. BEESACK AND J. E. PEČARIĆ, Integral inequalities of Čebyšev type, J. Math. Anal. Appl. 111 (1985), pp. 643-659.

[10] C. B. GAO AND J. J. Wen, Theory of surround system and associated inequalities, Comput. Math. Appl. 63 (2012), pp. 1621-1640.

[11] J. J. WEN AND W. L. WANG, Chebyshev type inequalities involving permanents and their application, Linear Algebra and its Applications, 422 (1) (2007), pp. 295-303.

[12] J. J. WEN AND Z. H. ZHANG, Jensen type inequalities involving homogeneous polynomials, Journal Inequlities and Applications, 2010, doi:10. 1155/2010/850215.

[13] J. E. PEČARIĆ, J. J. WEN, W. L. WANG AND T. LU, A generalization of Maclaurin's inequality and its applications, Math. Inequal. Appl. 8 (4) (2005), pp. 583-598. 